The use of the personal endings studied in this paper are distributed across these conjugational paradigms, hence in clarifying their history, one has to pay attention to these categories as well.

Clarifying the background of $1 \mathrm{sg}-k$ is the toughest nut to crack of all personal endings of Hungarian, yet it finally gave in; the key was that $3 \mathrm{sg}-i k$ of the medial conjugation is a complex of the former participial suffix $-i$ and the enhancer $-k$, together becoming the functional vehicle of mediality. With the full development of the medial conjugation, the emergence of the most frequently used personal endings, that is, the $2 \mathrm{sg}$ and especially $1 \mathrm{sg}$ verb forms, was inevitable. What turned into the ending of $2 \mathrm{sg}$ was $-l$, one of the threefold descendants of the $2 \mathrm{sg}$ personal pronoun (PU/PFU *-t- $>>\mathrm{H}-d,-l,-s z$ ); whereas 1 sg acquired its $-k$, coming from the former enhancer, by association with $-i k$, the exponent of mediality in $3 \mathrm{sg}$.

The detection of the pronominal origin of both $1 \mathrm{sg}-k$ and $1 \mathrm{pl}-(j) u k /-(j) u ̈ k$ became possible by ferreting out, in view of data from related languages, a number of facts and events of historical phonology, historical morphology, and morphosyntax.

Keywords: Ugric languages, personal pronoun, person-number ending, agglutination, historical phonology

\title{
Szóidőtartamok ismétlésben és spontán beszédben gyermekeknél ${ }^{1}$
}

\section{Bevezetés}

Az anyanyelv-elsajátítás során a gyermek a gőgicsélést követő időszakokban először szókezdeményeket mond, amelyek a környezetéből hallott szavak saját korlátozott artikulációjának a megvalósulásai. Ezek a szókezdemények, majd később a valódi szavak jó része a hallottak egyfajta ismétlései (Lengyel 1981; Clark 1995; Gósy 2005). Ez a hallásalapú ismétlés később, a gyermek önálló közléseinek, majd a hosszabb szövegeknek a megjelenésével csak az új szavakra korlátozódik. A hallott szavak vagy frázisok szó szerinti ismétlése, általában három-négy éves kor után, egyre ritkább lesz. Az anyanyelv-elsajátítás során a kezdetekben a sokszoros ismétlődésnek, a későbbiekben a szóemlékezetnek van döntő szerepe (Gathercole-Baddelely 1989). Már kéthárom éves kortól kezdve spontán közléseket mond a gyermek, amelyek egyre több szóból állnak, és fokozatosan kialakul a spontán beszéd többféle típusa, amelyek már jól mutatják a beszédtervezési folyamatok és a kiejtés fejlődését is. Ekkor a gyermek a szavakat a mentális lexikonából hívja elő és alakítja át morfológiailag, szintaktikailag a közlések létrehozásához (Levelt 1989). Relatíve gyorsan képes lesz narratívajellegü spontán közlések létrehozására, amelyek során emlékeiről, illetve élményeiről beszél hosszabban. Ezek a sajátos verbális nyelvi viselkedések már hároméves kortól tapasztalhatók, a beszédszövegek több tekintetben tükrözik a nyelvelsajátítás fejlődését

1 A kutatás a Nemzeti Kutatási, Fejlesztési és Innovációs Hivatal Tématerületi Kiválósági Programja (Közösségépítés: család és nemzet, hagyomány és innováció), valamint az NKFIH-K-120234 számú pályázat támogatásával készült. 
(Andó 2005; Lucero 2015). Mindebben a korábbi életkori szakaszokra jellemző közvetlen ismétléseknek már nincsen szerepük. Mások megnyilatkozásainak valamilyen szintü ismétlése azonban hosszú ideig jellemző lehet a gyermekek verbális kommunikációjában, az okok sokfélék (új szó tanulása, felnőtt kérésére történő ismétlés, tanulási céllal elvárt ismétlés stb.). A spontán közlések térnyerése az életkor előrehaladtával természetesen egyre nagyobb.

A különféle beszédmódok (kommunikációs helyzettől függő narratívák, társalgás, ismétlés, felolvasás stb.) számos tekintetben hasonló beszédprodukciós feladatot jelentenek a beszélőnek (életkortól függetlenül), mégis jelentős különbségek is jellemzik őket (Sachs-Devin 1976; Redford-Gildersleeve-Neumann 2009; KimStoel-Gammon 2010; Jacewicz et al. 2010; Colletta et al. 2010; Hazan et al. 2016). A jelen kutatásban két beszédmódot elemeztem, mondatismétléseket és spontán közléseket, amelyek között a memóriamüködés és a beszédtervezés felsőbb szintjeinek részvétele jelenti a legnagyobb eltérést (Jeffries et al. 2004; Okura-Lonsdale 2012; Henry 2012; Klem et al. 2015). E két beszédmódban különböznek a beszédfeldolgozás funkciói is. A mondatismétléses feladatban a produkciót megelőző dekódolási folyamat felsőbb szintjei (beszédmegértés, értelmezés) nem szükségszerüen vesznek részt, gyakran a beszédészlelésen alapuló ,,automatikus” ismétlés elegendő a feladat megoldásához (mindez természetesen nem független az ismétlendő szavaktól, a mondat jelentéstartalmától, a beszélő ismereteitől stb.). A szavak jelentésének ismerete, használati gyakorisága, a mondatok szemantikai tartalmának sikeres feldolgozása kétségkívül előnyt jelent, könnyebbé válik az elhangzottak megtartása és utánmondása (Klem et al. 2015). Ismétléskor a beszédészlelés, illetve a beszédmegértés a kiindulás, biztosítja a feladat teljesítését; a spontán közlések produkciójában pedig ellenőrző és a hibajavítást lehetővé tévő folyamatokként müködnek permanensen.

A hallottak megismétlésekor a beszédprodukció több folyamata (pl. szelekció, nyelvi átalakítás) nem aktív. Az ezekben végbemenő müveletekre ugyanis nincs szükség, hiszen a hallott mondatok tartalmazzák a gondolatnak megfelelö grammatikai szerkezetet, a szükséges szavakat, valamint a fonológiai és a fonetikai átalakításokat is. A produkciós mechanizmus ekkor bizonyos fokig egyszerüsített, ám nehezítést is tartalmaz, mivel a beszélő nem válogathatja meg szabadon a szavakat, a morfológiai struktúrákat, a grammatikai szerkezeteket, sőt az elhangzás sorrendjét is követnie kell. A mondatismétlés pontosságát meghatározza a jelentésreprezentáció, a lexikális hozzáférési folyamat, a szintaktikailag előfeszített mondatszerkezetek és a munkamemória (pl. Potter-Lombardi 1998; Jeffries et al. 2004; Klem et al. 2015; Gósy 2020a).

A spontán közlések produkciója komplex verbális feladat, amely az ismétléshez képest bizonyos értelemben kötetlenebb. Ekkor az adott gondolatnak megfelelö grammatikai szerkezetet és tartalmat kell a gyermeknek létrehoznia, ami a teljes beszédtervezési folyamat müködését igényli, de van választási lehetösége is (Levelt 1989). Bizonyos korlátozások, a nyelvi szabályok követése, a gondolatok válogatása, sorrendezése, a megfelelés ellenörzése stb. azonban nagyon összetetté teszik a beszédtervezési mechanizmus múködését.

Az emlékezet különféle módokon funkcionál a beszéd összes folyamatában, illetve a különféle beszédmódokban (Alloway-Gathercole 2005; Acheson-MacDonald 
2009; Turi et al. 2014). Ismétléskor a munkamemóriának van különösen kiemelt szerepe (pl. Alloway et al. 2004), a spontán beszéd létrehozásában pedig sajátosan érvényesül a rövid idejü és a hosszú idejü memória kölcsönhatása (pl. Aitchison 2003; Klem et al. 2015). A munkamemória müködését és kapacitását sok szempontból vizsgálták gyermekeknél (pl. Okura-Lonsdale 2012), és megállapították, hogy a nyelvelsajátítás egy bizonyos szakaszáig a munkamemória kapacitása folyamatosan nő (Baddeley 2001; Racsmány 2004). Ez önmagában is magyarázza azt, hogy az idősebb gyermekek mondatismétlési eredményessége jobb, mint a fiatalabbaké (Jeffries et al. 2004; Gósy 2020b).

Gyermekkorban a beszédhangok képzése még pontatlan, az időzítés bizonytalan, ennek az akusztikai-fonetikai következményei egyértelmüen tapasztalhatók (Auszmann 2018). Az anyanyelv-elsajátítás fejlödése során változnak a beszéd temporális viszonyai, például a beszédtempó, a beszédhangok, avagy azok részeinek időtartama (Smith et al. 1996; Jacewicz et al. 2010; Redford 2015; Hazan et al. 2016; Gósy-Krepsz 2017; Gósy 2018; stb.). Különböző anyanyelvü gyermekekkel végzett kísérletek igazolták, hogy az idősebbek rövidebben ejtik a szavakat, mint a fiatalabbak (pl. Smith et al. 1996; Lee et al. 1999; Tomasello 2003; Gósy 2020b). Az anyanyelvi kompetencia mind az ismétlésben, mind a spontán beszédben meghatározó (pl. Klem et al. 2015; Redford 2015). Feltehetően az idősebb gyermekek nagyobb beszédrutinja is érvényesül a produkcióban, függetlenül attól, hogy mondatokat ismételnek vagy spontán közléseket mondanak.

Az általam elemzett kétféle beszédmódban elméletileg hasonlónak tekinthetők a szükséges artikulációs gesztusok, ugyanakkor a kivitelezésüket nyilvánvalóan befolyásolja a gyermekkorú beszélők életkora. Különbséget jelenthet továbbá, hogy ismétlés esetén a beszélö mintát kap a kiejtésre vonatkozóan, vagyis a hallottak utánzására hatással lehet a közvetlen beszédprodukció. A spontán beszéd tervezési mechanizmusában nincs közvetlen minta, ekkor az ejtésre vonatkozó belső reprezentációk aktiválódnak, és jelennek meg az artikulációs gesztusokban. Felvetődik a kérdés, hogy a hangzási minta elönyt jelent-e a gyermekek beszédképzése számára ismétléskor szemben a spontán közlések belső reprezentációinak kifejeződésével. Amennyiben valószínúsítjük, hogy a hallott minta előny a reprodukálásban, akkor kézenfekvőnek tünik, hogy ez elsősorban a szavak időtartamában érhető tetten.

A kutatásban választ kerestem arra, hogy a szavak temporális viszonyai, illetve az időkontroll függ-e a beszédmódtól. Az elemzések rámutathatnak arra is, hogy a mondatismétlés vagy a spontán közlések létrehozása igényel-e nagyobb kognitív erőfeszítést, ami a szavak időtartamaiban (is) tetten érhető. Tudatában vagyok annak, hogy az időtartamok alakulására számos tényező hat, ezért a vizsgálatokban igyekeztem csökkenteni a változók számát, illetve az azokra ható tényezőket. Elemeztem a különböző szótagszám (egy szótagostól négy szótagosig), valamint a szótípus (tartalmas vagy funkciószó) hatását a szavak időtartamára mindkét beszédmódban. Valószínüsíthető, hogy a mondatismétlés (a kutatásban részt vevő 5 és 7 éves gyermekek számára) nehezebb feladat, mint a spontán közlések megfogalmazása egy interjúhelyzetben.

Mindezek alapján három hipotézist fogalmaztam meg: (i) az ismételt mondatok szavainak időtartama hosszabb lesz, mint a spontán közlésekben ejtetteké, 
(ii) az idősebb gyermekek szóidőtartamai rövidebbek lesznek mindkét beszédmódban, (iii) a szótagszám növekedésével a szavak időtartama relatív csökkenést fog mutatni mindkét beszédmódban, és (iv) a funkciószók rövidebbek lesznek, mint a tartalmas szavak mindkét beszédmódban.

\section{Kísérleti személyek, anyag, módszer}

A kutatáshoz ugyanazon 20 gyermek mondatismétléseit és spontán beszédszövegeit használtam fel. A hanganyagokat a GABI adatbázis (Bóna et al. 2014) felvételei közül véletlenszerüen választottam ki (tekintetbe véve az életkorukat és a nemüket). Az adatközlők közül 10 ötéves óvodás (5;2-5;7 korúak), 10 pedig hétéves iskolás (7;3-7;8 korúak) volt (mindkét csoportban a gyermekek fele kislány, fele kisfiú). Ép hallású, átlagos szociokulturális hátterü gyermekek.

A mondatismétlésekből és a spontán szövegekből választottam ki különféle szavakat. A szavak kiválasztásához a következő szempontokat állítottam össze. (i) Legyenek tartalmas és funkciószók, (ii) a szavak szótagszáma 1, 2, 3 és 4 legyen, (iii) a mondatok, illetve a spontán frázisok különböző helyein forduljanak elö (de ne kövesse öket szünet), (iv) az összevethetöség érdekében a kétféle beszédmódban ejtett szavak arányai a fenti tényezők szerint hasonlóak legyenek. Az 1. táblázat az elemzendő szavak számát összegzi életkoronként, a beszédmód és a szótagok száma szerint.

1. táblázat. Az elemzett szavak száma az életkor, a beszédmód és a szó típusa szerint (tart. = tartalmas szó, funk. $=$ funkciószó)

\begin{tabular}{|c|c|c|c|c|c|c|c|c|}
\hline Életkor & \multicolumn{4}{|c|}{5 évesek } & \multicolumn{4}{|c|}{7 évesek } \\
\hline db & \multicolumn{4}{|c|}{752} & \multicolumn{4}{|c|}{999} \\
\hline beszédmód & \multicolumn{2}{|c|}{ ismétlés } & \multicolumn{2}{|c|}{ spontán } & \multicolumn{2}{|c|}{ ismétlés } & \multicolumn{2}{|c|}{ spontán } \\
\hline db & \multicolumn{2}{|c|}{373} & \multicolumn{2}{|c|}{420} & \multicolumn{2}{|c|}{379} & \multicolumn{2}{|c|}{579} \\
\hline 1 szótagú & \multicolumn{2}{|c|}{102} & \multicolumn{2}{|c|}{106} & \multicolumn{2}{|c|}{107} & \multicolumn{2}{|c|}{212} \\
\hline 2 szótagú & \multicolumn{2}{|c|}{98} & \multicolumn{2}{|c|}{126} & \multicolumn{2}{|c|}{106} & \multicolumn{2}{|c|}{210} \\
\hline 3 szótagú & \multicolumn{2}{|c|}{85} & \multicolumn{2}{|c|}{103} & \multicolumn{2}{|c|}{77} & \multicolumn{2}{|c|}{96} \\
\hline 4 szótagú & \multicolumn{2}{|c|}{88} & \multicolumn{2}{|c|}{81} & \multicolumn{2}{|c|}{89} & \multicolumn{2}{|c|}{61} \\
\hline szó típusa & tart. & funk. & tart. & funk. & tart. & funk. & tart. & funk. \\
\hline db & 267 & 106 & 314 & 106 & 278 & 101 & 409 & 170 \\
\hline
\end{tabular}

Az ismétlendő anyag 15 mondatból állt. Például: A farsangi bálban mindenkinek szép jelmeze volt; Nemsokára odaérünk, ugye? A spontán szövegek átlagos időtartama 20 perc volt, ekkor a gyermekek az óvodáról, az iskoláról, illetve a szabadidejükről meséltek. Példa (részlet): utána mikor csöngetnek utána föl kell mennünk a terem terembe onnan kipakolunk amilyen óra lesz és megkérdezzük Éva nénit vagy Ili nénit hogy mehetünk-e ren reggelizni és akkor lemegyünk reggelizni (7 éves adat- 
közlö). Példák az elemzéshez kiválasztott szavakra ismétlésekből: víz, kérsz, föld, magyar, hosszú, bálban, farsangi, indulunk, gyermeke, bukfencezni, kiáltotta; hogy, így, miatt, ugye, keresztül, nemsokára. Példák a spontán szövegekből: ló, volt, kis, fiúk, kapott, édes, lányokat, sütöttem, féltékeny, iskolába, eljutottam; hogy, csak, és, azzal, tehát, alá, amibe, egyiket, ilyeneket, mindenféle.

A mondatismétléses feladatban az adatközlőnek hallás alapján, egyszeri elhangzást követően kellett a mondatot megismételnie. A spontán szövegek kétszemélyes társalgások alapján jöttek létre, ahol az interjúkészítő igyekezett csak akkor közbeszólni, avagy kérdést feltenni, ha arra a beszélgetés folytatása érdekében szükség volt (ez gyakrabban az 5 évesek esetében fordult elö). A spontán szövegek tehát döntően narratívajellegü közlések voltak.

Az ismétlésekből és a spontán szövegekből kiválasztott szavak időtartamát mértem meg. A szavakat annotáltam a Praat programban (Boersma-Weenink 2015). A szóhatárokat az akusztikai hullámforma és a szó hangszínképe alapján határoztam meg, folyamatos meghallgatással, ügyelve a megelőző és a követő szóval alkotott koartikulációs jelenségekre. Az időtartamok kinyerése az annotálás alapján történt, egy specifikus szkript segítségével automatikusan. Az időtartamok elemzése a következő szempontok szerint valósult meg: (i) életkor, (ii) beszédmód, (iii) szótagszám, (iv) tartalmas vagy funkciószó-e (szótípus). Tekintettel az adatközlők relatíve kis számára, a nemek közötti esetleges eltéréseket nem vizsgáltam. A statisztikai elemzésekhez egyváltozós varianciaanalízist használtam 95\%-os megbízhatósági szinten, illetve a Pearson-féle korrelációszámítást alkalmaztam (az SPSS 25.0 verziószámú programban). Minden esetben megadtam a parciális együttható értékét is (alkalmazott jelölés: $\eta^{2}$ ), amely a vizsgált tényező hatásának nagyságát jelzi. Azt mutatja meg, hogy a független változó (pl. az életkor vagy a beszédmód) milyen mértékben befolyásolja a függő változó varianciáját. (Minél közelebb van az érték az egyhez, annál erősebb a két változó közötti összefüggés, és minél távolabb, annál gyengébb, még akkor is, ha matematikailag szignifikáns eredményt kaptunk.)

\section{Eredmények}

A kutatás gyermek adatközlőinek átlagos szóidőtartama, a beszédmódtól függetlenül, 530 ms-nak adódott (átlagos eltérés $=270 \mathrm{~ms}$ ). Az összes adatot tekintve, a szóidötartamok rövidebbek voltak az idősebb (átlag $=486 \mathrm{~ms}$, átlagos eltérés $=254 \mathrm{~ms}$ ) és hosszabbak a fiatalabb gyermekek (átlag $=583 \mathrm{~ms}$, átlagos eltérés $=289 \mathrm{~ms}$ ) ejtésében. Nem csupán az átlagértékek különbözőek, de a szóródás is, ami nagyobb egyéni különbségekre utal a fiatalabb gyermekeknél. Az adatközlőink mindkét életkorban tendenciaszerüen rövidebben ejtették a spontán közlések szavait, mint az ismételt mondatokban előfordulókat. A mondatismétlések során ejtett szavak átlagos időtartama az 5 éveseknél $613 \mathrm{~ms}$ (átlagos eltérés $=289 \mathrm{~ms}$ ), a 7 éveseknél $530 \mathrm{~ms}$ (átlagos eltérés $=244 \mathrm{~ms}$ ). A különbség átlagosan mintegy $80 \mathrm{~ms}$. A spontán beszédben az 5 évesek szavainak átlagos időtartama $556 \mathrm{~ms}$ (átlagos eltérés $=268 \mathrm{~ms}$ ), a 7 évesekéi pedig $457 \mathrm{~ms}$ (átlagos eltérés $=251 \mathrm{~ms}$ ). Az átlagos időtartamot tekintve, a kü- 
lönbség az életkori csoportok szóidőtartamai között 99 ms. Összevetve az ismételt és a spontán ejtett szavak időtartamait ugyanazon életkori csoportban, azt látjuk, hogy a 7 éveseknél valamivel nagyobb a szóidőtartamok átlagának különbsége a beszédmód tekintetében, mint az 5 évesek esetében. Az összes időértéket figyelembe véve, a tartalmas szavak átlagos időtartama ötéveseknél 649 ms (átlagos eltérés $=275 \mathrm{~ms}$ ), a funkciószavaké $402 \mathrm{~ms}$ volt (átlagos eltérés $=200 \mathrm{~ms}$ ). A 7 évesek tartalmas szavainak átlagos időtartama 548 ms-nak (átlagos eltérés $=252 \mathrm{~ms}$ ), a funkciószavaké 330 ms-nak adódott (átlagos eltérés $=181 \mathrm{~ms}$ )

A szavak szótagszáma az ejtésük időtartamának egyik alapvetően meghatározó tényezője. Az adatok azt mutatják, hogy mind az ismétlések (1. ábra), mind a spontán közlések (2. ábra) esetében a gyermekek szavainak időtartamai lineárisan növekszenek. Az 5 évesek szavainak időtartamai között hasonlóak a különbségek a két beszédmódban, és minden esetben hosszabbak az ismétlésben. A 7 évesek ejtésében alig van különbség az egy szótagból álló szavak időtartamában a beszédmód függvényében, a két szótagosok esetében az ismételt szavak hosszabbak. A három és négy szótagból álló szavak hosszabb időtartamban realizálódtak a spontán beszédben, mint ismétléskor.

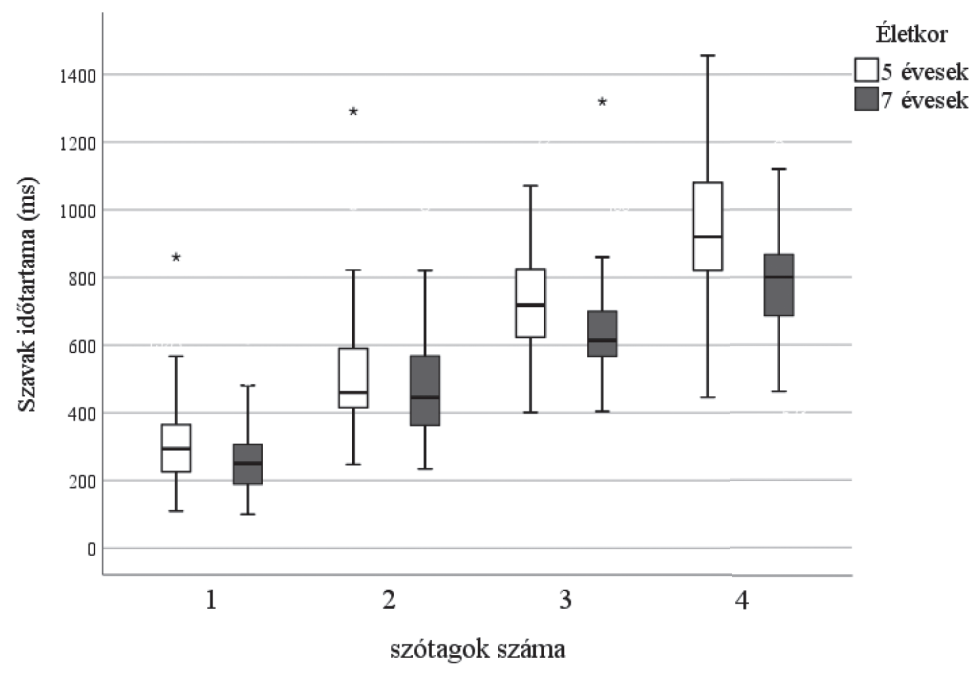

1. ábra. Ismételt mondatokban ejtett szavak időtartamai a két korcsoportban (medián és interkvartilis tartomány)

A statisztikai elemzések szerint a szavak időtartama mind az életkor $(F(1,1750)=$ 39,835, $\left.p=0,001, \eta^{2}=0,022\right)$, mind a beszédmód függvényében szignifikánsan különbözik $\left(F(1,1750)=5,447, p=0,002, \eta^{2}=0,003\right)$. A kettö kölcsönhatása (interakciója) is szignifikáns $\left(F(1,1750)=12,571, p=0,001, \eta^{2}=0,007\right)$, ami azt mutatja, hogy a két tényező hatása erősíti egymást, és befolyásolja a szavak ejtési tartamát. A hatásnagyságuk azonban kicsi. Az időtartamok a szavak szótagszámának függvényében szignifikánsan különböznek $\left(F(3,1750)=977,496, p=0,001, \eta^{2}=0,628\right)$. 


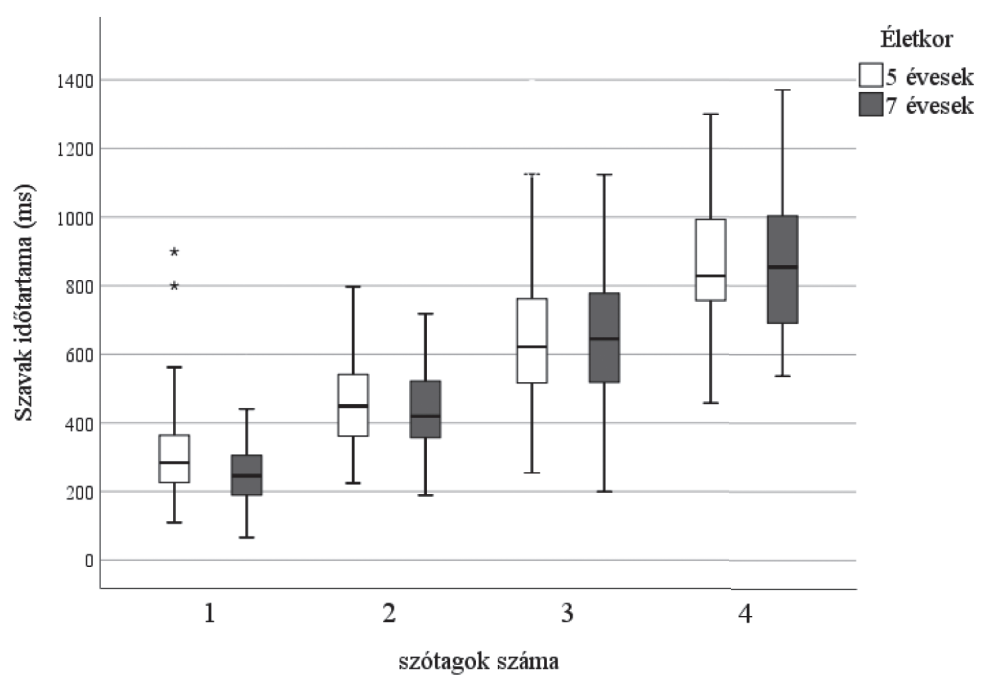

2. ábra. Spontán közlésekben ejtett szavak időtartamai a két korcsoportban (medián és interkvartilis tartomány)

A szótagszám nagy hatást gyakorol a szóidőtartamokra (ahogyan azt a parciális együttható értéke mutatja), és magyarázza az időtartamokra kapott adatok jelentős részét. A post hoc tesztek szignifikáns különbséget mutattak $(p<0,001)$ a különböző szótagszámú szavak időtartamai között. A beszédmód és a szótagszám interakciója nem volt szignifikáns $\left(F(3,1750)=1,511, p=0,210, \eta^{2}=0,003\right)$, hasonlóképpen az életkor és a szótagszám interakciója sem $\left(F(3,1750)=1,218, p=0,302, \eta^{2}=0,002\right)$. A szavak szótagszáma, a beszédmód és az életkor kölcsönhatása azonban szignifikáns $\left(F(3,1750)=4,504, p=0,004, \eta^{2}=0,008\right)$. A korrelációelemzés is megerösítette a szóidő és a szavak szótagszáma közötti erős összefüggést $(r=0,797, p=0,001)$, ugyanez tapasztalható mindkét beszédmódban, az ismétléseknél $(r=0,815, p=0,001)$ és a spontán ejtésü szavak esetében is $(r=0,777, p=0,001)$.

Elemeztem a szóidőtartamokat az életkor, a szótagszám és a szótípus függvényében ugyanazon beszédmódokban. Az ismételt szavak objektív időtartama a szótagszám növekedésével hosszabbodik; 5 éveseknél az egy szótagos szavak átlaga $312 \mathrm{~ms}$ (átlagos eltérés $=132 \mathrm{~ms}$ ), a két szótagosoké $516 \mathrm{~ms}$ (átlagos eltérés $=163 \mathrm{~ms}$ ), a három szótagosoké $733 \mathrm{~ms}$ (átlagos eltérés $=146 \mathrm{~ms}$ ) és a négy szótagosoké $955 \mathrm{~ms}$ (átlagos eltérés $=196 \mathrm{~ms}$ ). A 7 évesek megfelelő adatai: $261 \mathrm{~ms}$ (átlagos eltérés $=97 \mathrm{~ms}$ ), $481 \mathrm{~ms}$ (átlagos eltérés $=163 \mathrm{~ms}$ ), $643 \mathrm{~ms}$ (átlagos eltérés $=138 \mathrm{~ms}$ ) és $813 \mathrm{~ms}$ (átlagos eltérés $=180 \mathrm{~ms}$ ). Az eltérő életkorú csoportokban adatolt különbségek $51 \mathrm{~ms}$ és $35 \mathrm{~ms}$ az egy és két szótagból álló szavak esetében. A három és a négy szótagos szavaknál megnövekszenek a különbségek, az átlagértékek 90 ms és $142 \mathrm{~ms}$.

$\mathrm{Az}$ ismételt tartalmas és funkciószavak időtartama rövidebb az idősebb gyermekek ejtésében (3. ábra). A tartalmas szavak időtartama az 5 éveseknél átlagosan 691 ms-nak (átlagos eltérés $=278 \mathrm{~ms}$ ), a 7 éveseknél átlagosan $581 \mathrm{~ms}$-nak adódott (átlagos eltérés $=246 \mathrm{~ms}$ ). Lényegesen kisebb eltérést adatoltunk a funkciószók 
esetében, az átlagérték az 5 éveseknél 416 ms (átlagos eltérés $=213 \mathrm{~ms}$ ), a 7 éveseknél pedig $390 \mathrm{~ms}$ (átlagos eltérés $=219 \mathrm{~ms}$ ). A tartalmas szavaknál valamennyi szótagszámú szó esetében a fiatalabb gyermekek hosszabban ejtették a szavakat. A funkciószókat elemezve, az tapasztalható, hogy a két és a három szótagból állókat a 7 évesek ejtették hosszabban.

Az ismételt szavak időtartamai szignifikáns különbséget mutattak a szótagszám $\left.F(3,751)=278,475, p=0,001, \eta^{2}=0,532\right)$, a szavak típusa $(F(1,751)=22,377$, $\left.p=0,001, \eta^{2}=0,030\right)$ és az életkor $\left(F(1,751)=9,264, p=0,001, \eta^{2}=0,012\right)$ függvényében. Az életkor és a szótagszám $\left(F(3,751)=1,256, p=0,288, \eta^{2}=0,005\right)$, valamint a szótagszám és a szótípus $\left.F(3,751)=2,137, p=0,094, \eta^{2}=0,009\right)$ kölcsönhatása nem, de az életkor és a szótípus interakciója szignifikáns volt $(F(1,751)=$ 8,868, $\left.p=0,003, \eta^{2}=0,012\right)$. A szótagszám, a szótípus és az életkor interakciója nem volt szignifikáns $\left(F(3,751)=0,562, p=0,640, \eta^{2}=0,002\right)$. A post hoc tesztek minden esetben szignifikáns különbséget igazoltak a különböző szótagszámú szavak időtartamai között ( $p<0,001)$. Az életkori csoportokat külön-külön elemezve, a szavak idötartamai szignifikánsan különböztek mind a szótagszám ( 5 évesek: $F(3,372)=$ 154,650, $p=0,001, \eta^{2}=0,560 ; 7$ évesek: $\left.F(3,378)=131,823, p=0,001, \eta^{2}=0,516\right)$, mind a szavak típusának függvényében $\left(5\right.$ évesek: $F(1,372)=40,059, p=0,001, \eta^{2}=$ 0,099; 7 évesek: $\left.F(3,378)=1,240, p=0,266, \eta^{2}=0,003\right)$. A szótagszám és a szótípus interakciója sem az 5 éveseknél $\left(F(3,372)=0,878, p=0,453, \eta^{2}=0,007\right)$, sem a 7 éveseknél nem volt szignifikáns $\left(F(3,378)=1,725, p=0,161, \eta^{2}=0,014\right)$.

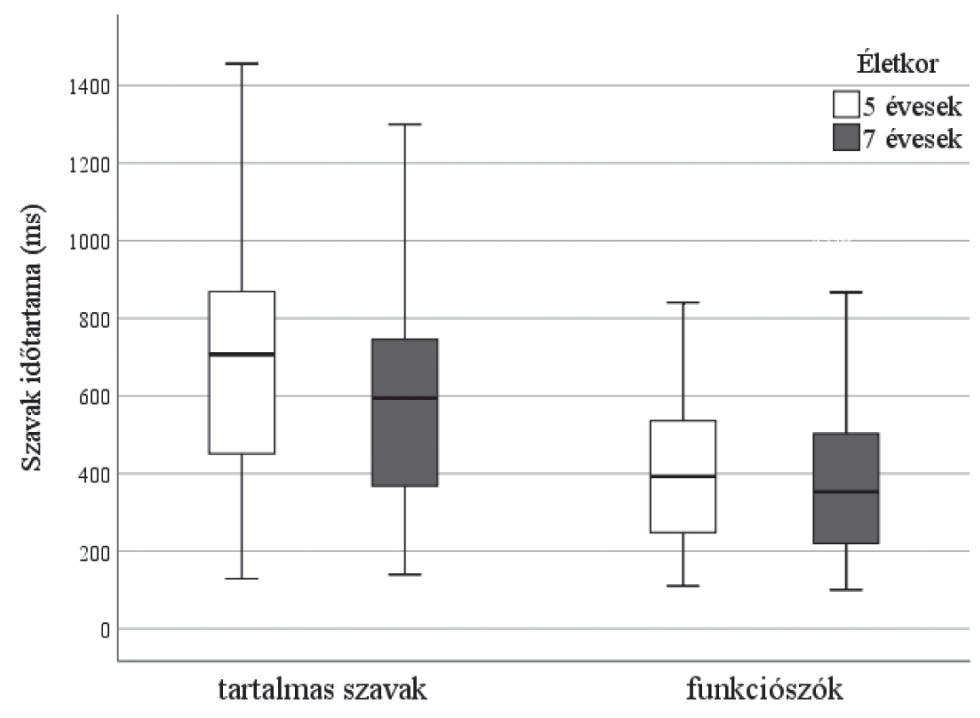

3. ábra. Ismételt mondatokban ejtett szavak időtartamai a két korcsoportban (medián és interkvartilis tartomány) 
Elemeztem, hogy a spontán ejtésủ szavak időtartama hogyan alakul az életkor, a szótagszám és a szótípus függvényében. Itt is az idősebb gyermekek produkálták a szavakat általában rövidebben. Az egy és két szótagos szavak átlagos időtartamai az 5 éveseknél hosszabbak ( $318 \mathrm{~ms}$ és $471 \mathrm{~ms}$; átlagos eltérés $=148 \mathrm{~ms}$ és $154 \mathrm{~ms}$ ), mint a 7 éveseknél ( $257 \mathrm{~ms}$ és $444 \mathrm{~ms}$; átlagos eltérés $=112 \mathrm{~ms}$ és $127 \mathrm{~ms}$ ); az átlagok különbségei $61 \mathrm{~ms}$ és $27 \mathrm{~ms}$. A három és a négy szótagos szavak átlagos időtartamában azonban nem volt jelentős eltérés a két életkori csoport között (5 évesek: 676 ms; átlagos eltérés $=204 \mathrm{~ms}$; 7 évesek: $665 \mathrm{~ms}$; átlagos eltérés $=208 \mathrm{~ms}$, illetve 5 évesek: $889 \mathrm{~ms}$; átlagos eltérés $=223 \mathrm{~ms}, 7$ évesek: $871 \mathrm{~ms}$; átlagos eltérés $=222 \mathrm{~ms}$ ). A 7 évesek szavai rövidebbek voltak ugyan, de a különbségek átlagosan $20 \mathrm{~ms}$ alattiak.

A tartalmas szavak időtartama az 5 éveseknél átlagosan 612 ms-nak (átlagos eltérés $=268 \mathrm{~ms}$ ), a 7 éveseknél pedig átlagosan $525 \mathrm{~ms}$-nak (átlagos eltérés $=254 \mathrm{~ms}$ ) adódott. A funkciószók átlagos időtartama 5 éveseknél $387 \mathrm{~ms}$ (átlagos eltérés = 185 ms), a 7 éveseknél pedig 294 ms (átlagos eltérés = 144 ms) (vö. 4. ábra). A tartalmas szavak esetében szótagszámtól függetlenül a fiatalabb gyermekek szóejtése volt hosszabb, a négy szótagból álló funkciószókat azonban az összes gyermek nagyon hasonló tartamban ejtette (5 évesek átlaga: 619 ms, a 7 éveseké: $622 \mathrm{~ms}$ ).

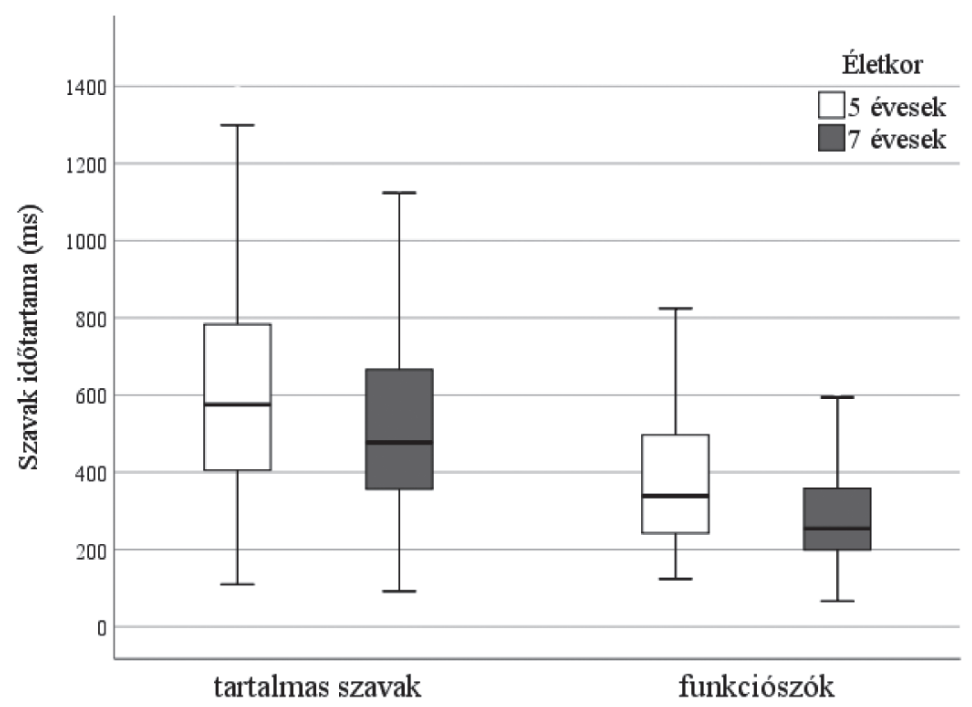

4. ábra. Spontán közlésekben ejtett szavak időtartamai a két korcsoportban (medián és interkvartilis tartomány)

A spontán ejtett szavak időtartamai szignifikáns különbségeket mutattak a szótagszám függvényében $\left(F(3,998)=185,337, p=0,001, \eta^{2}=0,362\right)$, a szótípus függvényében $\left(F(1,998)=78,717, p=0,001, \eta^{2}=0,074\right)$, az életkor függvényében azonban nem $\left(F(1,998)=3,517, p=0,061, \eta^{2}=0,004\right)$. A post hoc tesztek minden esetben 
szignifikáns különbséget igazoltak a különböző szótagszámú szavak időtartamai között (a $p$-érték mindenütt kisebb, mint 0,001). A szótagszám és a szótípus interakciója szignifikáns volt $\left(F(3,998)=11,404, p=0,001, \eta^{2}=0,034\right)$, a szótagszám és az életkor kölcsönhatása nem $\left(F(3,998)=0,743, p=0,527, \eta^{2}=0,002\right)$, hasonlóan a szótípus és az életkor $\left(F(1,998)=0,268, p=0,605, \eta^{2}=0,001\right)$ és a szótagszám, a szótípus és az életkor interakciója $\operatorname{sem}\left(F(3,998)=0,691, p=0,558, \eta^{2}=0,002\right)$. Az életkori csoportokat külön-külön elemezve, a szavak időtartamai szignifikánsan különböztek a szótagszám (5 éveseknél: $F(3,419)=79,375, p=0,001, \eta^{2}=0,367$; 7 éveseknél: $\left.F(3,578)=118,446, p=0,001, \eta^{2}=0,384\right)$ és a szavak típusának függvényében ( 5 éveseknél: $F(3,419)=13,578, p=0,001, \eta^{2}=0,367 ; 7$ éveseknél: $\left.F(1,578)=45,352, p=0,001, \eta^{2}=0,074\right)$. A szótagszám és a szótípus interakciója szignifikáns volt mindkét életkori csoportban (5 éveseknél: $F(3,419)=6,593$, $p=0,001, \eta^{2}=0,046 ; 7$ éveseknél: $\left.F(3,578)=5,681, p=0,001, \eta^{2}=0,029\right)$.

\section{Következtetések}

A kutatás azt vizsgálta, hogy a szavak időtartamai miként realizálódnak mondatismétléskor és spontán közlésekben ötéves óvodás és hétéves iskolás gyermekek ejtésében. Választ kerestem arra a fó kérdésre, hogy vajon a beszédmód eredményez-e különbséget a gyermekek objektív szóidőtartamaiban. A szavak hosszúságának és a szótípusnak a hatását is elemeztem a két vizsgált beszédmódban elhangzott szavak időtartamainak tekintetében.

A szavak temporális jellemzőit elsősorban az határozza meg, hogy hány szótagból épülnek fel. Az adatközlök életkora a jelen kutatás spontán közléseiben mért szóidőtartamok esetében nem volt meghatározó, az ismételt szavak tartamára azonban hatást gyakorolt. Mindkét beszédmódban és mindkét életkori csoportban jellemzően különbözött az elemzett szavak időtartama a szótípustól függően. Magától értetődően számos további tényező befolyásolja az ejtési időtartamot. Az idősebb gyermekek ejtésében általában rövidebbek voltak a szavak, mint a fiatalabbaknál, a szóidőtartamok értékei természetesen mutattak átfedéseket, olykor azonosságokat az életkori csoportok között. Ez az eredmény várható volt a nemzetközi és a hazai szakirodalmi adatok alapján (pl. Redford 2015; Gósy-Krepsz 2017). A két évvel idősebb gyermekek artikulációs gesztusai már jóval stabilabbak, mint a fiatalabbakéi, a beszédtervezési müveletek nagyobb mértékben automatikusak, a temporális kontroll fejlettebben müködik.

Az óvodás és az iskolás gyermekek egyaránt rövidebben ejtették a spontán közlések szavait, mint az ismételt mondatokban előfordulókat. A beszédmód hatását tükrözte az időtartamokban az a tény, hogy az ismétlés során a gyermek hangzási mintát kapott, míg a spontán beszédben relatíve szabadon választotta meg és aktiválta a lexikális hozzáférés céllexémáját. Nyilvánvalóan könnyebb és gyorsabb a jól ismert szavak kiejtése szemben a ritkán vagy akár sosem használtakkal, mint például kalauz, minap, forgalom, odaérünk (noha az adatközlők egyéni mentális lexikonának feltöltöttsége nem ismert). A spontán közlésekben a gyermekek - élet- 
kortól függetlenül - rendszerint a gyakran használt (hallott és mondott) szavakat aktiválják és produkálják. Spontán beszédkor a rejtett beszédtervezési mechanizmus egyidejü müveletei egyfajta gyorsításra ösztönzik a beszélöt. A gyermek is igyekszik relatíve rövid időtartamban kiejteni a szavakat, hogy az újabb fogalmaknak megfelelö előhívási és átalakítási folyamatokat müködtetni tudja. A spontán közlések grammatikai szerkesztettsége tükrözi a gyermek nyelvi kompetenciáját, bizonyos gyakorisági előfordulásokat és egyfajta beszédrutint. Ezekhez a közlésekhez képest az ismételt mondatok szerkezete és szavai készen kapottak, és gyakorlatilag függetlenek a gyermekek grammatikai és szókincset érintő kompetenciájától. Feltehetően az is hatást gyakorol az időzítési viszonyok alakulására, hogy az ismétlés ötéves korban már ritkábban előforduló beszédmód a mindennapokban. A spontán ejtésü és az ismételt szavak időtartama nem korrelált egymással, ami arra utal, hogy az egyik értékéböl nem következtethetünk a másik értékére.

A hétéveseknél kissé nagyobb a szóidőtartamok átlagának különbsége a beszédmód tekintetében, mint az ötévesek esetében. Ez valószínüsíthetően összefügg az iskolások fejlettebb artikulációs gesztusaival, a könnyebben és gyorsabban ,,programozható" temporális jellemzőkkel a spontán közlésekben. A mentális lexikonból előhívott szavak időzítési reprezentációja biztosabb és jobban állandósult, mint az óvodások esetében. A temporális kontroll is az idősebbeknél müködik valószínüsíthetően jobban.

A szótagszám növekedésével az elemzett szavak szótagjainak időtartamában relatív csökkenés bekövetkezése volt várható (Lee et al. 1996; Smith et al. 1999; GósyKrepsz 2017). Ez mindkét életkorban és mindkét beszédmódban be is következett. A csökkenés mind az ismétlésben, mind a spontán közlésekben az idősebb gyermekek ejtésére volt jellemzőbb, azaz ők általában nagyobb mértékben redukálták a hosszabb szavakat a kiejtésben, mint a fiatalabbak. Az ismételt szavak esetében a hétéveseknél kifejezettebb volt a redukálódás, mint a spontán ejtettek időtartamaiban. A redukálódás mértékének ez az eltérése a beszédmód függvényében azt tükrözi, hogy az ötévesek spontán ejtett szavainak időtartamai megközelítik a hétévesekéit. Ez a három és a négy szótagból álló szavak esetén különösen feltünő volt. A valószínü okok - amelyek további elemzéseket igényelnek - a hétévesek spontán beszédében, a frázisok hosszában és a közlések grammatikai (szemantikai) komplexitásában keresendők. Úgy gondolom továbbá, hogy magyarázat lehet az is, hogy a hétévesek a spontán közléseikben sok olyan hosszabb szót ejtettek, amelyek használati gyakorisága (még) relatíve alacsony (az iskolával, szabadidős tevékenységgel kapcsolatos újabb szavak). Például: technika, döntetlen, edzésre, csapatunknak, íróverseny, büvészkészlet, barkácsasztalt, bordásfalig. A következö, három és négy szótagból álló szavak az ötévesek közléseiből szemléltetik a különbséget: dínókat, fekete, boszorkány, állatokat, bújócskáztunk, szobájába, homokozunk. A szavak hossza (szótagokban kifejezve) és az időtartamuk között erős korrelációt találtam mind az ismétlések, mind a spontán közlések esetén.

A funkciószók általában később jelennek meg nagyobb számban a gyermekek beszédében a tartalmas szavakhoz képest (pl. Gósy 2005; Lengyel 1981). Utóbbiak a magyar nyelv agglutináló jellege miatt meglehetősen változók, míg a funkciószók formailag állandók. Az angolban végzett statisztikai elemzések szerint a funk- 
ciószók rövidebbek, mint a tartalmas szók, és a rövidebb funkciószók használata gyakoribb (Miller et al. 1958). Ugyancsak angol nyelvüek olvasott szövegeinek vizsgálatakor találtak különbséget a tartalmas és a funkciószók lexikális hozzáférésében (Schmauder et al. 2000), és igazolták a funkciószók rövidebb aktiválási idejét (Bell et al. 2009). A jelen kutatás azt támasztotta alá, hogy a gyermekek ejtésében mindkét beszédmódban rövidebbek voltak a funkciószók. Messzemenő következtetéseket ebböl azonban még nem vonhatunk le, az azonban valószínüsíthetö, hogy ennek az az oka, hogy az állandó formájú (tehát nem toldalékolható) funkciószók rövidebb ejtése a szükséges artikulációs gesztusok relatív változatlanságának a következménye. Az a tény, hogy a két és a három szótagból álló funkciószókat a hétévesek kismértékben hosszabban ejtették, a négy szótagosok esetében pedig alig volt különbség az időtartamokban az életkor szerint, utalhat arra, hogy az idősebb gyermekek egyrészt jobban törekedhettek a pontos ejtésre, másrészt a megszokottakon kívül ritkábban elöforduló funkciószókat is használtak a közléseikben. Például: eléggé, olyankor, valamikor, nemsokára.

A hipotézisek nagyrészt teljesültek. Feltételeztem, hogy az ismételt mondatok szavainak időtartama hosszabb lesz, mint a spontán közlésekben ejtetteké, ezt a fiatalabb gyermekek adatai igazolták. Az idősebb gyermekek esetében az időértékek csak részben támasztották alá a feltevést, mivel a hétévesek a három és négy szótagos szavakat ismétléskor ejtették rövidebben. Úgy gondoltam, hogy az idősebb gyermekek szóidőtartamai rövidebbek lesznek, mint a fiatalokéi, amit az ismételt szavak időtartamai igazoltak, a spontán ejtésüekéi azonban csak részben. Az a hipotézis, hogy a szótagszám növekedésével a szavak időtartama relatív csökkenést fog mutatni mindkét beszédmódban, teljesült, de az időviszonyok különbségének mértékében eltérés is tapasztalható a beszédmód és az életkor függvényében. Végül, igazolódott, hogy a gyermekek a funkciószókat rövidebben ejtették, mint a tartalmas szavakat mindkét beszédmódban.

Az elemzett beszédanyagok szavainak időtartamai alátámasztják a szavak hoszszúságának (esetünkben a szótagszámnak), az életkornak és a beszédmódnak a kétségtelen hatását a temporális viszonyok alakulására gyermekeknél; a hatásnagyság azonban erősen változónak igazolódott. A szavak hossza és az időtartamok összefüggése alapján kijelenthető, hogy már ötéves korban müködnek a redukciós folyamatok, amelyek két évvel később még határozottabban tapasztalhatók. A gyakorlottabb artikuláció és a spontán beszédben a beszélő szándéka szerint elöhívott szavak következtében jönnek létre a rövidebb időtartamú szavak. A tartalmas és a funkciószók időzítési különbsége ugyancsak igazolható már az ötéveseknél is, és ez a használati gyakorisággal, az állandó fonológiai/fonetikai formával és a vélhetően gyorsabb lexikális hozzáféréssel magyarázható.

A beszédmódok okozta eltérések több tényezö hatása(i)ként értelmezhetök, úgymint a beszédmód használati különbsége, az emlékezeti differenciák, a mentális lexikon más módon történő aktiválása, a produkciós mechanizmus müveleti különbségei. Nem mondható ki teljes bizonyossággal, hogy az időzítési eltérések kizárólag a beszédmód következményei; hiszen az emlékezeti tényezők, az egyéni kommunikációs sajátosságok, az anyanyelv-elsajátítás fejlődésének ténye, a figye- 
lem müködése (stb.) is felelősek a temporális jellemzők alakulásáért. A kapott adatok ugyanakkor jó kiindulást jelentenek a további vizsgálatokhoz.

Az eredmények - kissé áttételesen ugyan -, de gyakorlati vonatkozásokra is ráirányítják a figyelmet. Az ismételt szavak relatíve hosszú időtartamai a beszédészlelés, a szókincs, illetve a verbális memória fokozott fejlesztésének szükségességére utalnak. Az a tény, hogy a spontán közlésekben a hétévesek hasonló tartamban produkálták a szavakat, mint az ötévesek, felveti azt, hogy szükség van a verbális kommunikáció gyakoriságának a növelésére. Minél több alkalmat biztosítunk a gyermekeknek a korlátozások nélküli spontán közlésekre, annál biztosabban fogják tudni kifejezni magukat. Az időzítésnek pedig mindebben nagy a szerepe.

\section{SZAKIRODALOM}

Acheson, Daniel J. - MacDonald, Maryellen C. 2009. Verbal working memory and language production: Common approaches to the serial ordering of verbal information. Psychological Bulletin 135/1: 50-68. https://doi.org/10.1037/a0014411

Aitchison, Jean 2003. Words in the mind. An introduction to the mental lexicon. Basil Blackwell, Malden.

Alloway, Tracy Packiam, Gathercole, Susan E. 2005. Working memory and short-term sentence recall in young children. European Journal of Cognitive Psychology 17/2: 20720. https://doi.org/10.1080/09541440440000005

Alloway, Tracy Packiam - Gathercole, Susan E. - Willis, Catherine - Adams, Anne-Marie 2004. A structural analysis of working memory and related cognitive skills in young children. Journal of Experimental Child Psychology 87: 85-106. https://doi.org/10.1016/j. jecp.2003.10.002

Andó Éva 2005. „Tarka lepke, kis mese...” A történetmondás szerepe a nyelvi szocializáció folyamatában. In: Balázs Géza - Grétsy László (szerk.): Nyelv és nyelvhasználat a családban. Tinta Kiadó, Budapest, 7-32.

Auszmann Anita 2018. Magyar gyermekek magánhangzóinak akusztikai-fonetikai jellemzői. ELTE Eötvös Kiadó, Budapest.

Baddeley, Alan D. 2001. Az emberi emlékezet. Osiris Kiadó, Budapest.

Bell, Alan - Brenier, Jason M. - Gregory, Michelle - Girand, Cynthia - Jurafsky, Dan 2009. Predictability effects on durations of content and function words in conversational English. Journal of Memory and Language 60: 92-111. https://doi.org/10.1016/j.jml.2008.06.003

Boersma, Paul - Weenink, David 2015. Praat: doing phonetics by computer. http://www.fon. hum.uva.nl/praat/down-load_win.html (Letöltve: 2016. november 18.)

Bóna Judit - Imre Angéla - Markó Alexandra - Váradi Viola - Gósy Mária 2014. GABI Gyermeknyelvi beszédadatbázis és információtár. Beszédkutatás 2014: 246-51.

Clark, Eve 1995. Later lexical development and word formation. In: Fletcher, Paul MacWhinney, Brian (eds.): The handbook of child language. Blackwell, Oxford, 393412. https://doi.org/10.1111/b.9780631203124.1996.00016.x

Colletta, Jean-Marc - Pellenq, Catherine - Guidetti, Michèle 2010. Age-related changes in co-speech gesture and narrative: Evidence from French children and adults. Speech Communication 52: 565-76. https://doi.org/10.1016/j.specom.2010.02.009

Gathercole, Susan E. - Baddeley, Alan D. 1989. Evaluation of the role of phonological STM in the development of vocabulary in children: A longitudinal study. Journal of Memory and Language 28: 200-13. https://doi.org/10.1016/0749-596X(89)90044-2 
Gósy Mária 2005. Pszicholingvisztika. Osiris Kiadó, Budapest.

Gósy Mária 2018. Hiátusos kontextusok temporális mintázata gyermekek beszédében. Beszédkutatás 2018: 110-33.

Gósy Mária 2020a. Szótagszám és szóhosszúság gyermekek mondatismétlésében. In: Fóris Ágota - Bölcskei Andrea (főszerk.) - Bóna Judit - Gráczi Tekla Etelka - Markó Alexandra (szerk.): Nyelv, kultúra, identitás. Alkalmazott nyelvészeti kutatások a 21. századi információs térben. III. Fonetika. (A MANYE Kongresszusok Előadásai 12/3.) Akadémiai Kiadó, Budapest, 343-49.

Gósy Mária 2020b. Durations of words with various numbers of syllables across childhood. In: Taschenberger, Linda (ed.): Book of Abstracts of 2nd Workshop on Speech Perception and Production across the Lifespan (SPPL2020). Economic and Social Research Council (ESRC) and Division of Psychology and Language Sciences, UCL, London, 3-5.

Gósy Mária - Krepsz Valéria 2017. Morfémák időzitési mintázatai a beszédben. MTA Nyelvtudományi Intézet, Budapest.

Hazan, Valerie L. - Tuomainen, Outi-Pettinato, Michèle 2016. Suprasegmental characteristics of spontaneous speech produced in good and challenging communicative conditions by talkers aged 9 to 14 years old. Journal of Speech, Language, and Hearing Research 69/6: 1-19. https://doi.org/10.1044/2016_JSLHR-S-15-0046

Henry, Lucy 2012. The development of working memory of children. Sage Publications, London. https://doi.org/10.4135/9781446251348

Jacewicz, Ewa - Fox, Robert Allen - Wei, Lai 2010. Between-speaker and within-speaker variation in speech tempo of American English. Journal of the Acoustical Society of America 128: 839-50. https://doi.org/10.1121/1.3459842

Jeffries, Ralph - Baddeley, Alan 2004. Automatic and controlled processing in sentence recall: The role of long-term and working memory. Journal of Memory and Language 51: 623-43. https://doi.org/10.1016/j.jml.2004.07.005

Kim, Minjung - Stoel-Gammon, Carol 2010. Segmental timing of young children and adults. International Journal of Speech and Language Pathology 12/3: 221-29. https://doi. org/10.3109/17549500903477363

Klem, Marianne - Melby-Lervåg, Monica - Hagtvet, Bente Eriksen - Halaas, SolveigAlma - Gustafsson, Jan-Eric - Hulme, Charles 2015. Sentence repetition is a measure of children's language skills rather than working memory limitations. Developmental Science 18: 146-54. https://doi.org/10.1111/desc.12202

Lee, Sungbok - Potamianos, Alexandros - Narayanan, Shrikanth S. 1999. Acoustics of children's speech: Developmental changes of temporal and spectral parameters. Journal of the Acoustical Society of America 105: 1455-68. https://doi.org/10.1121/1.426686

Lengyel Zsolt 1981. Tanulmányok a nyelvelsajátitás köréböl. Akadémiai Kiadó, Budapest.

Levelt, Willem J. M. 1989. Speaking. From Intention to Articulation. MIT Press, Cambridge.

Lucero, Audrey 2015. Cross-linguistic lexical, grammatical, and discourse performance on oral narrative retells among young Spanish speakers. Child Development 86/5: 1419-33. https://doi.org/10.1111/cdev.12387

Miller, George A. - Newman, E. B. - Friedman, E. A. 1958. Length-frequency statistics for written English. Information and Control 1: 370-89. https://doi.org/10.1016/S00199958(58)90229-8

Okura, Eve - Lonsdale, Deryle. 2012. Working memory's meager involvement in sentence repetition tests. Conference: Cognitive Science, 2132-37.

Potter, Mary C. - Lombardi, Linda 1998. Syntactic priming in immediate recall of sentences. Journal of Memory and Language 38: 265-82. https://doi.org/10.1006/jmla.1997.2546

Racsmány Mihály 2004. A munkamemória szerepe a megismerésben. Akadémiai Kiadó, Budapest. 
Redford, Melissa A. 2015. The acquisition of temporal patterns. In: Redford, M. A. (ed.) The handbook of speech production. Wiley, Blackwell, New Jersey, 379-403. https://doi. org/10.1002/9781118584156.ch17

Redford, Melissa A. - Gildersleeve-Neumann, Christina E. 2009. The development of distinct speaking styles in preschool children. Journal of Speech, Language and Hearing Research 52/6: 1434-48. https://doi.org/10.1044/1092-4388(2009/07-0223)

Sachs, Jacqueline - Devin, Judith 1976. Young children's use of age-appropriate speech styles in social interaction and role-playing. Journal of Child Language 3/1: 81-98. https://doi. org/10.1017/S030500090000132X

Schmauder, Rene A. - Morris, Robin K. - Poynor, David V. 2000. Lexical processing and text integration offunction and content words: Evidence from priming and eye fixations. Memory and Cognition 28/7: 1098-108. https://doi.org/10.3758/BF03211811

Smith, Bruce L. 1992. Relationships between duration and temporal variability in children's speech. Journal of the Acoustical Society of America 91/4: 2165-74. https://doi. org/10.1121/1.403675

Smith, Bruce L. - Kenney, Mary Kay - Hussain, Sarmad 1996. A longitudinal investigation of duration and temporal variability in children's speech production. Journal of the Acoustical Society of America 99: 2344-49. https://doi.org/10.1121/1.415421

Tomasello, Michael 2003. Constructing a language. A usage-based theory of language acquisition. Harvard University Press, Cambridge.

Turi Zsolt - Németh Dezső - Hoffmann Ildikó 2014. Nyelv és emlékezet. In: Pléh Csaba Lukács Ágnes (szerk.): Pszicholingvisztika. Akadémiai Kiadó, Budapest, 743-76.

\author{
Gósy Mária \\ egyetemi tanár \\ ELKH Nyelvtudományi Intézet, \\ ELTE Alkalmazott Nyelvészeti és Fonetikai Tanszék \\ https://orcid.org/0000-0003-4336-3007
}

\title{
SUMMARY
}

Gósy, Mária

\section{Duration of words produced in repetitions and spontaneously with children}

The present study intended to analyze word durations both in sentence repetitions and in spontaneous speech samples produced by 5-year-old and 7-year-old Hungarian-speaking children. The durations of the older children's words were significantly longer than those of the younger children in repetitions but not in spontaneous speech. The number of the syllables was a particularly decisive factor in durations. The reduction tendency of the longer words was characteritic of all children's pronunciation, and it was specifically marked with the 7-year-old children in repeated words. Function words were produced shorter than content words by all children in both speech styles. Temporal patterns of words are good indicators for developing articulation, lexical access, and speech motor control.

Keywords: words of various lengths, speech styles, durations, word types, 5- and 7-yearolds 